\title{
A RARE CAUSE OF HYPOCALCAEMIA: PSEUDOHYPOPARATHYROIDISM
}

GULAY ALP ${ }^{1}$, NILUFER OZDEMIR KUTBAY $^{2}$, BANU SARER YUREKLI², EMIN KARACA ${ }^{3}$, MEHMET ERDOGAN $^{2}$, SEVKI CETINKALP $^{2}$, GOKHAN $^{2}$ OZGEN $^{2}$, FERDA OZKINAY ${ }^{3}$, FUSUN SAYGILI²

EGE UNIVERSITY FACULTY OF MEDICINE, INTERNAL MEDICINE DEPARTMENT, IZMIR, TURKEY1

EGE UNIVERSITY FACULTY OF MEDICINE, ENDOCRINOLOGY AND METABOLISM DEPARTMENT, IZMIR,TURKEY²

EGE UNIVERSITY FACULTY OF MEDICINE, MEDICAL GENETICS DEPARTMENT, IZMIR,TURKEY 3

\section{Objectives:}

Pseudohypoparathyroidism (PHP) is a rare disease characterized by end-organ resistance to parathyroid hormone, causing hypocalcemia with hyperphosphatemia and elevated parathormone (PTH) levels. A prevalence of $3.4 /$ million has been reported. Here, we present a rare case with PHP.

\section{Case:}

A 28-year-old male patient with spasms in hands and feet was evaluated in the outpatient department of neurology and was referred to endocrinology clinic due to calcium level of $5.9 \mathrm{mg} / \mathrm{dL}$. Physical examination results: He had facial dysmorphism. Trousseau and Chvostek signs were positive. Moderate mental retardation was observed. Laboratory tests results: Serum total Ca: $5.7 \mathrm{mg} / \mathrm{dL}(8,2-10,6 \mathrm{mg} / \mathrm{dL}), \mathrm{P}: 5.9 \mathrm{mg} / \mathrm{dL}$ (3-5mg/dL), PTH (intact): $873 \mathrm{U} / \mathrm{l}$ (12-88 pg/ml), uric acid: 2,3 mg/dL (3,5-7,2 mg/dL) 24-hour urinary Ca: $9 \mathrm{mg}$ and urinary P:441 mg. Serum vitamin D level: $29 \mathrm{nmol} / \mathrm{L}$. Urine cAMP and Gsa subunit assays were not available in the tests. The roentgenogram of the hands revealed that he had short bilateral fifth metacarps and soft tissue calcifications in his left hand and bilateral forearm (Figure 1). His electrocardiogram was normal. QTc interval was $42 \mathrm{~ms}$. In Cranial CT, symmetrical diffuse calcifications were observed in both hemispheres and in the central part of the caudate nucleus and the level of nuclei lentiform of the basal ganglia (Figure 2).

Conclusions:

PHP is classified as types $1 \mathrm{a}, 1 \mathrm{~b}, 1 \mathrm{c}$ and type 2. Patients with type 1a have hypocalcamia, hyperphosphatemia and elevated serum PTH. These patients are characterized by short stature, obesity, moderate mental retardations, round faces, dental hypoplasia and brachydactyly; shortening of the metacarpal bones particularly the third, the fourth and the fifth as well as the features of Albrights hereditary osteodystrophy. PHP type 1 is inherited in an autosomal dominant pattern. GNAS gene is located on chromosome $20 q 13$ and defects are heterogeneous and complex. Our patient didn't have GNAS mutations (but we only looked at exon 8).
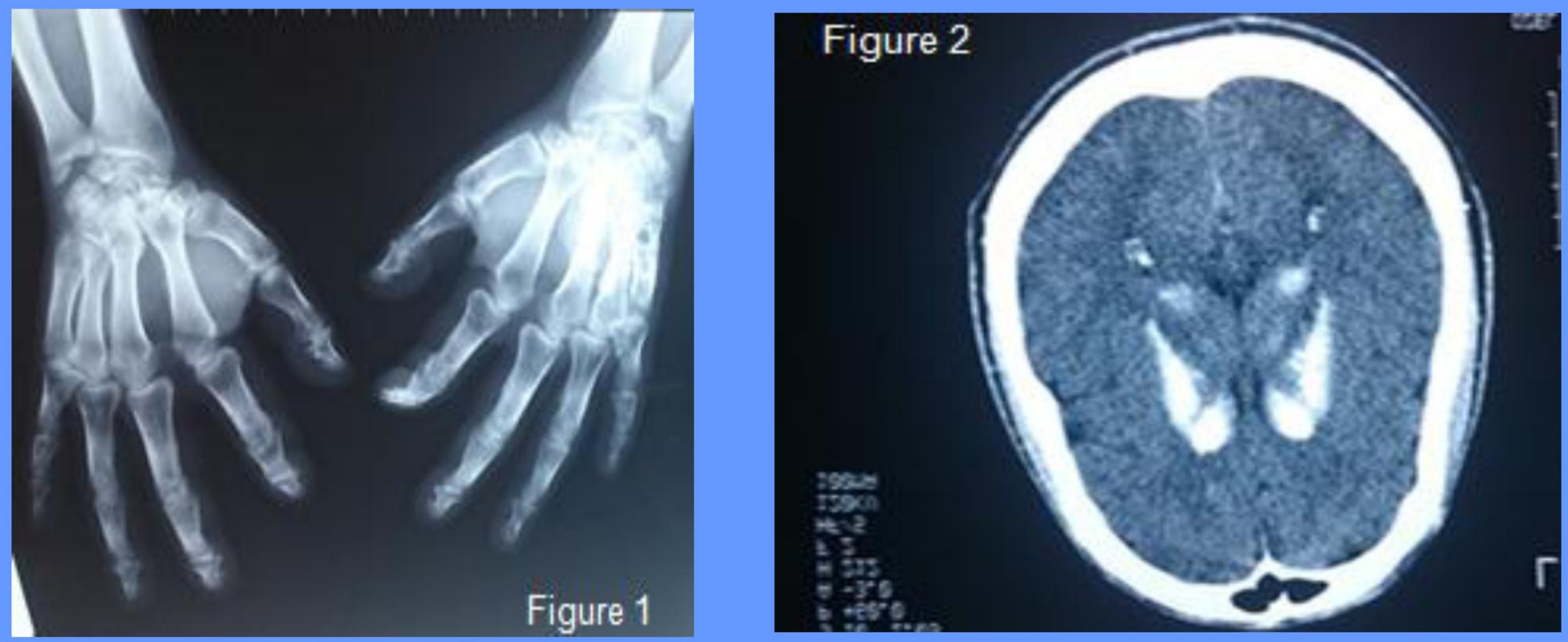